\title{
The Development Process Of Hemsball According To The Views Of Hemsball Coaches
}

\author{
Burcu Tuğlu
}

\section{ARTICLE INFO}

Article History:

Received 01.04.2016

Received in revised form

29.05.2016

Accepted 22.06.2016

Available online Tarih

girmek için burayı

tiklatin.

\begin{abstract}
Hemsball has been supported by Sports for All Federation (HIS) since 2012 and was also approved as the sports branch by the Ministry of Youth and Sports of Turkish Republic in 2013. In the current study, one of the qualitative research methods, semi-structural interview method was used. The final form of the study was given according to the views of specialists. The study group of this study consist of 20 hemsball coaches, who are working in various cities in Turkey. The data obtained from the interviews was analysed with the descriptive analysis method. In the present study, 5 open-ended questions were asked regarding the dissemination process of hemsball sport, things to be done in order to reach more students, effects of the implementation of the sport at schools, how to incorporate with the families and the expected physiological, psychological and sociological changes that the players can face. According to the results obtained from the study, the dissemination process of hemsball sport is as it should be, more hemsball courses should be opened, this sport can help the children's physical, psychomotor and psychological development, to increase the inclusion of families to the process, firstly works should be done with the families whose children are doing hemsball sport, it should also help the development of the musculoskeletal system.
\end{abstract}

C 2016 IJERE. All rights reserved

Keywords:

Hemsball, Hemsball Coaches, New Generation Sports, Dissemination of Sports

\section{INTRODUCTION}

Sporting activities provide people a healthy life, increase self-confidence and courage, teach success, defeat, hope and sharing. It also develops the ability to make immediate decisions, to support attention and coordination ( Hergüner, 1991).Fast and continuous changes in every field reveal regular updates and innovations related to the field. Recently, with the increased interest in high quality and healthy life, sporting events has begun to gain importance. Firstly, the governments should take into consideration to this issue and should take a role on the development of perception and dissemination of doing sports. For this reason, the governments should organize, develop and disseminate sporting events in countries. In a society, the applicability and dissemination of the different activities that have various rules and styles in practice is quite important (Sunay and Saracaloğlu,1997). Sport, one of the main parts of the modern people, has the ability to bring together the elements that make up the society. Starting at an early age, it contributes to the healthy development. Sport allows children to recognize their environment, to increase their confidence, to find a place within the society, to concentrate on a certain topic and to supply motivation to succeed (Sevim,2002).

People who do sports regularly and continuously lead to a healthy life. When the related researches are examined, it is seen that muscles, cardio-vascular and respiratory systems are affected positively thanks to regular exercises ( Demir and Filiz, 2004). Studies have also revealed that hemsball can also be used for the physical activities of the disabled (Todorova and et. al, 2014). Participation of the mentally disabled children in sporting activities provides them to strengthen muscles and to develop coordination, stability and flexibility ( Biçer and et al, 2004). Concentration on the appropriate stimuli and the ability to proceed the attention seem an important factor for success in sports. In this scope, attention and concentration abilities of athletes must be developed( Çağlar and Koruç, 2006).

Corresponding e-mail: burcutuglu20@hotmail.com 
Sporting events help people gain some characteristics; for instance, the people doing team sports learn to work in cooperation and the people doing individual sports learn to comply with the community rules (Kuru and Baştuğ, 2008).Children find ways to evaluate their own emotional, physical and mental capacities with the help of games and sports. If they are passive, they can lead an active role and control others thanks to games and sports. Games and sports let children express themselves actively ( Tiryaki, 2008).

It is a well-known fact that people who do sports regularly are more active, healthy and conscious. Therefore, the dissemination of sports by summer sporting schools will affect the general public health and the number of healthy people in a society ( Aydın, 2008). Families who support their children with sports help them gain good habits. Starting sports at an early age has a significant role on children's development. They can establish good relations within the society ( Kotan, Hergüner and Yaman, 2009). Sport has an important effect on gaining positive personality characteristics, increasing self confidence, having social personality, making accurate decisions by practical thinking and being mentally, physically and spiritually healthy (İlhan and Gencer,2009). Students who are healthy and physically more active are academically more successful and their motivation is higher than the sedentary students. According to the research, it can be claimed that sporting habits of students affects their social and emotional development positively ( Sözen and Doğan, 2010). Sporting events that are indispensable part of our social and cultural life have a significant role on people's adaption to society, taking responsibility and coping with stress. Positive reinforcement of families towards participation of their children in sporting facilities is of significant importance in gaining the habit of doing sports regularly (Öncü and Güven, 2011).

Recently, new sports have a growing tendency for social change in the society. It is seen as an efficient vehicle for the expected social changes within the society( Lyras and Peachey, 2011). Related studies show that physical activities during the childhood affect children's physical development positively. Regular and continuous exercises are of significant importance in terms of cognitive, emotional and physical development ( Çelik and Şahin, 2013). When the related studies are examined, it is seen that regular physical activity during childhood ensures higher level of physical activity consciousness (Dalkıran and Aslan, 2015). This study is important regarding the dissemination process of hemsball sport. It aims to provide the opinions of hemsball coaches during the dissemination process of the sport.

\section{METHODOLOGY}

In this research, one of the qualitative research methods, the semi-structural interview method was used. The final form of the study was given according to the views of specialists. 5 open-ended questions were asked to the hemsball coaches regarding the dissemination process of hemsball sport. The hemsball coaches answered the questions sincerely about the things to be done in order to reach more students, the effects of the implementation of the sport at schools, how to incorporate with the families and the expected physiological, psychological and sociological changes that the players can face. . The study group of this research consist of 20 hemsball coaches, who are working in various cities in Turkey. This study group consists of 5 females and 15 males. The average age is 33,15. The data obtained from the interviews was analysed with the descriptive analysis method. While analyzing the data, a thematic view was established. All the information obtained from the data was classified into themes by the researchers and coded seperately. After this process, the common themes were determined and the hemsball coaches who were interviewed were coded like H1, H2, H3... . 


\section{FINDINGS}

The hemsball coaches' comments about the dissemination process of hemsball sport are shown in tables below. The views of hemsball coaches about the dissemination of hemsball sport are stated in Table-1 :

Table 1. The views of hemsball coaches about the dissemination of hemsball sport

\begin{tabular}{|c|c|c|c|}
\hline $\begin{array}{l}\text { Theme } \\
\text { (Category) }\end{array}$ & Codes & $\mathbf{n}$ & $\%$ \\
\hline \multirow{5}{*}{$\begin{array}{l}\text { Dissemination } \\
\text { process }\end{array}$} & $\begin{array}{l}\text { It proceeds as it should be. } \\
(\mathrm{H} 1, \mathrm{H} 5, \mathrm{H} 6, \mathrm{H} 9, \mathrm{H} 12, \mathrm{H} 13, \mathrm{H} 15, \mathrm{H} 17, \mathrm{H} 19)\end{array}$ & 9 & 45 \\
\hline & $\begin{array}{l}\text { It proceeds with a great pace thanks to the coaching courses and } \\
\text { promotions. } \\
(\mathrm{H} 2, \mathrm{H} 4, \mathrm{H} 8, \mathrm{H} 10, \mathrm{H} 11, \mathrm{H} 14, \mathrm{H} 16, \mathrm{H} 20)\end{array}$ & 8 & 40 \\
\hline & $\begin{array}{l}\text { Sports for All Federation (HIS) contributes more to disseminate the } \\
\text { hemsball sport.(H8, H10, H17, H19) }\end{array}$ & 4 & 20 \\
\hline & $\begin{array}{l}\text { We should benefit more from the visual and written press. } \\
(\mathrm{H} 4, \mathrm{H} 7, \mathrm{H} 16, \mathrm{H} 18)\end{array}$ & 4 & 20 \\
\hline & $\begin{array}{l}\text { The process is inefficient. } \\
(\mathrm{H} 2, \mathrm{H} 3, \mathrm{H} 18)\end{array}$ & 3 & 15 \\
\hline
\end{tabular}

When we analyze Table 1, $\% 45$ of the hemsball coaches have stated that the process proceeds as it should be. And the others in order, $\% 40$ it proceeds with a great pace thanks to the coaching courses and promotions, \%20 Sports for All Federation (HIS) contributes more to disseminate the hemsball sport, \%20 we should benefit more from the visual and written press, and \%15 the process is inefficient.

The quotations taken one-to-one from the hemsball coaches' comments are:

"What is done for the dissemination of hemsball proceeds what it should be." (H1)

"In spite of being a new sport, it proceeds in a great pace." (H8)

"The process goes forward systematically. With the support of Sports for All Federation, it has reached more people." (H17)

"I think, it is growing fast thanks to the coaching courses taking place consecutively and the promotion that have been held by the hemsball coaches." (H4)

"In my opinion, the promotions haven't been done systematically." (H18)

The views of hemsball coaches about what should be done to reach more students are stated in Table-2:

Table 2. The views of hemsball coaches about what should be done to reach more students

\begin{tabular}{|c|c|c|c|}
\hline Theme & Codes & $\mathbf{n}$ & $\%$ \\
\hline \multirow{5}{*}{$\begin{array}{l}\text { Things to be } \\
\text { done to reach } \\
\text { more students }\end{array}$} & $\begin{array}{l}\text { More hemsball courses should be opened. } \\
\text { (H1, H4, H6, H7, H8, H10, H17, H18) }\end{array}$ & 8 & 40 \\
\hline & $\begin{array}{l}\text { The Ministry of Youth and Sports should cooperate with the Ministry of } \\
\text { Education. } \\
(\mathrm{H} 2, \mathrm{H} 8, \mathrm{H} 9, \mathrm{H} 14, \mathrm{H} 16, \mathrm{H} 18)\end{array}$ & 6 & 30 \\
\hline & $\begin{array}{l}\text { Entertaining activities, such as tournaments should be held. } \\
(\mathrm{H} 3, \mathrm{H} 11, \mathrm{H} 13, \mathrm{H} 15, \mathrm{H} 17)\end{array}$ & 5 & 25 \\
\hline & $\begin{array}{l}\text { It should be included in school sports. } \\
\text { (H3, H12, H13, H17, H19) }\end{array}$ & 5 & 25 \\
\hline & $\begin{array}{l}\text { Social media, television and internet should be used in accordance with the } \\
\text { purpose. } \\
(\mathrm{H} 5, \mathrm{H} 18, \mathrm{H} 20)\end{array}$ & 3 & 15 \\
\hline
\end{tabular}

When we analyze Table 2, the\% 40 of the coaches have stated that more hemsball courses should be opened.The other comments are, \%30 of the coaches stated that The Ministry of Youth and Sports should cooperate with the Ministry of Education, $\% 25$ of the coaches stated that entertaining activities, such as tournaments should be held, $\% 25$ of the coaches stated that it should be included in school sports, and \%15 
of the coaches stated that social media, television and internet should be used in accordance with the purpose.

The quotations taken one-to-one from the hemsball coaches' comments are:

"The Ministry of Youth and Sports should make an agreement with the Ministry of Education." (H2)

"To reach more students at schools, award-winning tournaments should be held." (H3)

"More promotions should be done to all levels at schools, and it has a great importance that more courses should be opened." (H4)

"If we want to disseminate our official sport, the Ministry of Youth and Sports and the Ministry of Education should work together." (H18)

"Since it isn't included in school sports, physical education teachers don't give enough interest to this sport. If it is included in school sports, more students will benefit from this." (H12)

The views of hemsball coaches about the effects of the implementation of Hemsball sport at schools are stated in Table-3:

Table 3. The effects of the implementation of hemsball sport at schools

\begin{tabular}{llcc}
\hline Theme (Category) & Codes & $\mathbf{n}$ & \% \\
\cline { 2 - 3 } & $\begin{array}{l}\text { It should help children's physical, psychological and psychomotor } \\
\text { development. (H4, H7, H9, H10, H11, H14, H15, H17, H18, H20) }\end{array}$ & 10 & 50 \\
Effects of the & $\begin{array}{l}\text { It should play a significant role on increasing the attention and } \\
\text { implementation }\end{array}$ & $\begin{array}{l}\text { concentration of children. (H4, H10, H11, H12, H14, H15, H16, H19, H20) } \\
\text { It should help children adapt to society. }\end{array}$ & 75 \\
& $\begin{array}{l}\text { (H1, H3, H5, H10, H12, H17, H19) } \\
\text { It should be helpful to reach more people. (H2, H8, H12, H13) }\end{array}$ & 4 & 20 \\
It should help children stay away from bad habits. (H1, H10, H17, H18) & 4 & 20 \\
& $\begin{array}{l}\text { It should help children think versatile and practical. } \\
\text { (H1, H11, H16) }\end{array}$ & 3 & 15 \\
& The implementations at schools won't be effective. (H6) & 1 & 5 \\
\hline
\end{tabular}

When we analyze Table 3, the $\% 50$ of the coaches have stated that the implementation of the Hemsball sport at schools should help children's physical, psychological and psychomotor development. And the others in order; $\% 45$ of them have stated that it should play a significant role on increasing the attention and concentration of children, $\% 35$ of them have stated that it should help children adapt to society, $\% 20$ of them have stated that it should help children stay away from bad habits, $\% 15$ of them have stated it should help children think versatile and practical and $\% 5$ of them have stated that the implementations at schools won't be effective.

The quotations taken one-to-one from the hemsball coaches' comments are:

"In my opinion, it will help children's stability, coordination, movement, psychomotor and also their psychological development. "(H4)

"During my training period, I have noticed that it has become effective on children's lack of attention and discipline problems. On the other hand, if it is implemented at schools, it will reach to more parents." (H12)

"It will increase children's physical capacity. It will lead children to acquire skills and coordination." (H7)

"Perhaps it will be useful for children's free time activities, but I don't think it will be very helpful in general." (H6) 
The views of hemsball coaches about the inclusion of families during the dissemination process of Hemsball sport are stated in Table-4 :

Table 4. The inclusion of families during the dissemination process of hemsball sport

\begin{tabular}{llcc}
\hline Theme(Category) & Codes & $\mathbf{N}$ & $\%$ \\
\hline & $\begin{array}{l}\text { At first, more activities should be done with the families, whose children } \\
\text { have already been playing hemsball. (H1, H2, H6, H7, H8, H10, H12, H13, }\end{array}$ & 13 & 60 \\
& H14, H15, H16, H17, H20) & 7 & 35 \\
$\begin{array}{l}\text { Inclusion of the } \\
\text { families to the } \\
\text { process }\end{array}$ & $\begin{array}{l}\text { Projects should be developed. (H3, H4, H5, H8, H11, H16, H17) } \\
\text { Parents should be given information about this sport at the meetings. (H7, }\end{array}$ & 6 & 30 \\
& $\begin{array}{l}\text { H8, H9, H15, H18, H19) } \\
\text { Promotions should be made through television, newspapers and social } \\
\text { media. (H13, H14) }\end{array}$ & 2 & 10 \\
\hline
\end{tabular}

When we analyze the table $4, \% 60$ of the coaches have mentioned that at first, more activities should be done with the families, whose children have already been playing hemsball. And the others in order; $\% 35$ of them have mentioned that projects should be developed, \%30 of them have mentioned that parents should be given information about this sport at the meetings, $\% 10$ of them have mentioned that promotions should be made through television, newspapers and social media.

The quotations taken one-to-one from the hemsball coaches' comments are:

"I have opened a course for the families whose children are playing hemsball. At first, I allow these families to be aware of this sport." (H2O)

"Families adapt any kind of thing easily which their children are involved in any activities. For this reason, Families will be more aware of the sport that their children are playing." (H2)

"Families should be included in the process by developing projects like 'I am doing sports with my children'." (H16)

"At the meetings held in schools, parents should be given information about this sport." (H8)

"The more children we reach, the more families will be involved in the process. Television, newspapers and social media should be used for promotions." (H18)

"With adult education centers, families should be given courses on this subject." (H14)

The views of hemsball coaches about the expected physiological, psychological and sociological changes that the players can face are stated in Table- 5 :

Table 5. Expected physiological, psychological and sociological changes that hemsball players can face

\begin{tabular}{|c|c|c|c|}
\hline $\begin{array}{l}\text { Theme } \\
\text { (Category) }\end{array}$ & Codes & $\mathbf{n}$ & $\%$ \\
\hline \multirow{4}{*}{$\begin{array}{l}\text { Physiological, } \\
\text { psychological } \\
\text { and sociological } \\
\text { changes }\end{array}$} & $\begin{array}{l}\text { It should help the development of the musculoskeletal system. } \\
(\mathrm{H} 2, \mathrm{H} 3, \mathrm{H} 7, \mathrm{H} 8, \mathrm{H} 9, \mathrm{H} 10, \mathrm{H} 11, \mathrm{H} 12, \mathrm{H} 13, \mathrm{H} 14, \mathrm{H} 15, \mathrm{H} 17, \mathrm{H} 18, \mathrm{H} 19)\end{array}$ & 14 & 70 \\
\hline & $\begin{array}{l}\text { It should increase the stability, focusing, attention and concentration skills. } \\
(\mathrm{H} 1, \mathrm{H} 3, \mathrm{H} 4, \mathrm{H} 6, \mathrm{H} 7, \mathrm{H} 11, \mathrm{H} 13, \mathrm{H} 14, \mathrm{H} 15, \mathrm{H} 17, \mathrm{H} 18, \mathrm{H} 20)\end{array}$ & 12 & 60 \\
\hline & $\begin{array}{l}\text { It should be effective in children's adaptation to society and socializing. } \\
(\mathrm{H} 2, \mathrm{H} 3, \mathrm{H} 4, \mathrm{H} 5, \mathrm{H} 7, \mathrm{H} 8, \mathrm{H} 9, \mathrm{H} 14, \mathrm{H} 15, \mathrm{H} 16, \mathrm{H} 18, \mathrm{H} 19)\end{array}$ & 12 & 60 \\
\hline & It should play an important role in increasing self confidence. & 4 & 20 \\
\hline
\end{tabular}




\section{(H1, H2, H16, H17)}

It should be helpful in the development of hand-eye coordination. (H10, H15, H17)

It should be effective in reducing behaviour disorders by providing motion control. (H1, H4, H19)

When we analyze the table 5, \%70 of the coaches have expressed that it should help the development of the musculoskeletal system. And the others in order; \%60 of them have expressed that it should increase the stability, focusing, attention and concentration skills, \%60 of them have expressed it should be effective in children's adaptation to society and socializing, \%60 of them expressed it should play an important role in increasing self confidence, $\% 15$ of them have expressed that it should be helpful in the development of handeye coordination and \%15 of them have stated that it should be effective in reducing behaviour disorders by providing motion control.

The quotations taken one-to-one from the hemsball coaches' comments are:

"Stability, attention, focusing and concentration are the main benefits of this sport." (H13)

"Firstly, it will help children stand in balance, focus on, and do the right movement. So, children feel successful and psychologically feel great. It can strengthen the muscles of the waist, back, leg and arm." (H18)

"Physiologically, motor skills; psychologically, mental health; sociologically, solidarity and sharing will be directly affected." (H9)

"Benefits of sport in general can also be seen with the hemsball sport. It will help people be physically healthy and fit, psychologically more social and extrovert, sociologically conformist and moral.

\section{CONCLUSION AND DISCUSSION}

In this research, the views of hemsball coaches about the dissemination process of hemsball, one of the sports under development have been stated and the situation what has been done until now and the necessity of what should be done have been examined.

When the gathered information has studied carefully, Hemsball coaches have emphasized that the dissemination period proceeds as it should be. And this shows that what has been done until now has affected the process positively.

From the information obtained from the coaches' views, The existing courses can be widened in order to accelerate the process. It has also been identified that more promotions and entertaining activities should be held in order to provide the participation to the courses.

Hemsball coaches have also emphasized that social media, television and internet should be used in accordance with the purpose. The fact that hemsball isn't included in school sports now has been thought as a negative side of the dissemination process. For hemsball coaches it is an important factor for not reaching more students.

Since hemsball can be played easily at any place, it is easy to implement at schools. It isn't necessary to have special sports fields so as to play hemsball. Due to the ease implementation, it has seen as a positive development.

While hemsball is played, players throw the ball into the hemsball hoop and make it go to the other side and prevent the other player from achieving the same goal. So, the right movements must be done by focusing on the target point by the players .For this reason, players who play regulary should develop high concentration, stability, hand-eye coordination, motion control, attention and focusing. With the implementation of hemsball sport at schools, it has been emphasized that children's physical, psychological and psychomotor development will be positively affected ( www.hemsball.com ). This has also seen as the another positive side of the sports by hemsball coaches.

To reach more people during the dissemination period of hemsball, the necessity of the inclusion of families to the process has been emphasized. The fact that activities should especially be done with the families whose children is taking hemsball courses will positively affect the process. Hemsball coaches have also 
stated in accordance with their experience that families adapt any kind of thing easily which their children are involved in. Therefore, families whose children are playing hemsball are more likely to aware of the sport.

According to the data given by the coaches, it has mostly been emphasized that hemsball should help the development of the musculoskeletal system. It is a well-known fact that doing sports systematically helps the development of the muscles.

Overall, as in other sports, hemsball will also be effective in children's gaining good habits, being healthy, fit, sociable and moral. It can also play a supplementary role within the training periods of other sports.

\section{SUGGESTIONS}

To increase the quality in life, people should be encouraged to do sports regularly.

At an early age, families should allow children to start doing sports. For this reason, while the programs are being developed in primary schools, specialists should pay attention the positive effects of sporting activities. Schedules of schools should be revised in terms of future needs.

Television and social media should be used for promotions about the importance and necessity of doing sports.

With national and international projects, more people should be involved in the sporting facilities.

Since the ease implementation of hemsball at any place, it can also be preferred as an alternative to other sports at schools.

Hemsball coaches should use positive reinforcement during their training process to increase the children's interest and motivation.

While planning the training, children's ages and physiological situations should be considered carefully.

Since it will help children provide motion control and reduce the behaviour disorders, physical education lessons should be planned according to this.

To increase the awareness of the sport within the society, an effective school-family cooperation should be provided.

To become a good model for students, teachers should be encouraged to attend seminars and courses about doing sports regularly.

The Ministry of Youth and Sports should cooperate with the Ministry of Education about the implementation of hemsball at schools. Hemsball should be expanded in stages.

Including hemsball as a lesson in the programs of all departments of faculty of education as well as department of physical education and sports will be effective and useful. 


\section{REFERENCES}

Aydın, A.D. (2008). Türkiye'de sporun topluma yaygınlaştırılması sürecinde yaz spor okullarının rolünün belirlenmesi. Journal of Physical Education and Sports Sciences, 10(1).

Biçer, Y. , Savucu, Y. , Kutlu, M. , Kaldırımcı, M. \& Pala, R. (2004). Güç ve kuvvet egzersizlerinin zihinsel engelli çocukların hareket beceri ve yeteneklerine etkisi. Doğu Anadolu Bölgesi Araştırmaları.

Çağlar, E. \& Koruç, Z. (2006). D2 dikkat testinin sporcularda güvenirliği ve geçerliği. Spor Bilimleri Dergisi: Hacettepe Üniversitesi, 58-80.

Çelik, A. \& Şahin, M. (2013). Spor ve çocuk gelişimi. The Journal of Academic Social Science Studies, 6(1), 467478.

Dalkıran, O. \& Aslan, C.S. (2015). Sporcu öğrenciler ile sedanter öğrencilerin sağllk-egzersiz ve fiziksel aktivite bilinç düzeylerinin karşılaştırılması. Uluslararası Güncel Eğitim Araştırmaları Dergisi (UGEAD), Aralık, 1, 34-41.

Demir, M. \& Filiz, K. (2004). Spor egzersizlerinin insan organizması üzerindeki etkileri. Ahi Evran Üniversitesi Kırşehir Eğitim Fakültesi Dergisi, 5(2)

Hergüner, G. (1991). Çocuğun spora yönelmesinde ailenin rolü ve önemi. Ondokuz Mayıs Üniversitesi Ĕ̆itim Fakültesi Dergisi, 6(1), 91-95.

İlhan, L., \& Gencer.,E. (2009). Çocuklarda nevrotik sorun düzeyleri ve badminton eğitimi ilişkisine yönelik bir araştırma. Kocaeli Üniversitesi 4. Raket Sporları Sempozyumu, Bildiriler Kitabı, (94-101).

Kotan, Ç. , Hergüner, G. \& Yaman, Ç. (2009). İlköğretim okullarında okuyan sporcu öğrencilerin spor yapmalarında okul ve aile faktörünün etkisi(Sakarya il örneği). Beden Eğitimi ve Spor Bilimleri Dergisi, 3(1).

Kuru, E., \& Baştuğ, G. (2008). Futbolcuların kişilik özellikleri ve bedenlerini algılama düzeylerinin incelenmesi. SPORMETRE Beden Ĕ̆itimi ve Spor Bilimleri Dergisi, 95-101.

Lyras, A. \& Peachey, J.W. (2011). Integrating sport-for-development theory and praxis. Sport Management Review, 14(4), 311-326.

Öncü, E. \& Özbay, G. (2011). Ana-babaların çocuklarının beden eğtimi dersine katılımına yönelik tutumları. Spor ve Performans Araştırmaları Dergisi, 2(2).

Sevim, Y. (2002). Antrenman Bilgisi, Ankara: Nobel Yayınevi.

Sözen, H. \& Doğan, E. (2010). Seviye belirleme sınavının ilköğretim öğrencilerinin spor yapma alışkanlığı üzerine etkisi. Kafkas Üniversitesi Sosyal Bilimler Enstitü Dergisi, 1(5).

Sunay, H., \& Saracaloğlu, A.S. (2003). Türk sporcusunun spordan beklentileri ile spora yönelten unsurlar. Spormetre Beden Eğitimi ve Spor Bilimleri Dergisi,1(1), 43-48.

Şahin, O. (2007). Düzenli egzersiz eğitiminin 12-14 yaş çocukların bazı fiziksel ve fizyolojik parametrelerin üzerine etkisinin incelenmesi, Konya, Selçuk Üniversitesi Sağllk Bilimleri Enstitüsü, Beden Eğitimi ve Spor Anabilim Dalı,Yüksek Lisans Tezi.

Tiryaki, Ş. (2008). Spor Psikolojisi. Ankara: Eylül Yayıncllık.

Todorova, R., Dimkova, R., Valova, T., \& Marcheva, P. (2014). Hemsball oyunu ve oyunun engelli çocukların psiko-fiziksel gelişimine etkisi ve aile görüşleri. International Journal of Science Culture and Sport, Special Issue on the Proceedings of the 3rd ISCS Conference SI(1): 665-693. 